\title{
PEMODELAN JUMLAH KASUS COVID-19 DI JAWA BARAT MENGGUNAKAN GEOGRAPHICALLY WEIGHTED REGRESSION
}

(Modeling The Number Of Covid-19 Case In West Java Using Geographically Weighted Regression)

\author{
Ilham Faishal Mahdy \\ Departemen Statistika, Universitas Padjadjaran \\ Iham19016@mail.unpad.ac.id
}

\begin{abstract}
ABSTRAK
Pada akhir tahun 2019, terjadi fenomena virus yang mematikan yang disebut dengan Covid-19. Pemerintah Indonesia menerapkan pembatasan sosial berskala besar (PSBB) dalam upaya menekan penyebaran Covid-19. Dalam prakteknya, masih terjadi pelanggaran terhadap PSBB yang dilakukan masyarakat, salah satu penyebabnya adalah kesenjangan ekonomi. Dalam penelitian ini terfokus pada pemodelan jumlah kasus Covid-19 di Provinsi Jawa Barat menggunakan Geographically Weighted Regression (GWR), yang merupakan pengembangan dari regresi linier bersifat lokal antar wilayah observasi. Adapun faktor yang dianggap mempengaruhi penyebaran Covid-19 adalah kepadatan penduduk, persentase kemiskinan, tingkat pengangguran terbuka, persentase rumah tangga dengan sanitasi layak, dan persentase rumah tangga dengan sumber air minum layak. Hasil penelitian menunjukkan bahwa penyebaran Covid-19 di sebagian besar wilayah Provinsi Jawa Barat dipengaruhi oleh persentase kemiskinan.
\end{abstract}

Kata kunci: Covid-19, Geographically Weighted Regression, Jawa Barat.

\section{ABSTRACT}

At the end of 2019, there was a deadly virus phenomenon called Covid-19. In order to reduce the spread of Covid-19, Indonesia Government implement large-scale social restrictions (PSBB). In reality, there are still violations against PSBB by society, one of the causes is economic inequality. This research will be focused on modelling the number of covid-19 case in West Java Province using Geographically Weighted Regression (GWR), which is the development of local linear regression between the observation areas. The factors that are considered to influence the spread of Covid-19 are population density, percentage of poverty, open unemployment rate, percentage of households with proper sanitation, and percentage of households with proper drinking water sources. The results showed that the spread of Covid-19 in most areas of West Java Province was influenced by the percentage of poverty.

Keywords: Covid-19, Geographically Weighted Regression, Jawa Barat.

\section{PENDAHULUAN}

World Health Organization (WHO) menjelaskan bahwa Covid-19 adalah virus yang menginfeksi sistem pernapasan. Sampai saat ini terdapat 188 negara yang mengkorfirmasi terkena virus Corona, salah satunya Indonesia (Hanoatubun, 2020). Pada tanggal 2 Maret 2020, tercatat 2 warga Depok dinyatakan positif Covid-19 di Indonesia. Penyebaran pun terus meluas di Nusantara. Hingga pada tanggal 31 Maret 2020, Presiden Indonesia, Joko Widodo menandatangani Peraturan Pemerintah Nomor 21 Tahun 2020 yang mengatur pembatasan sosial berskala besar (PSBB) sebagai respons terhadap Covid-19. Pada saat yang sama, Keputusan Presiden Nomor 11 Tahun 2020 juga ditandatangani, yang menyatakan pandemi korona virus sebagai bencana nasional. Pembuatan kedua peraturan tersebut didasarkan pada Undang-Undang Nomor 6 Tahun 2018 tentang Kekarantinaan Kesehatan, yang mengatur ketentuan mendasar untuk PSBB. 
Pandemi COVID-19 yang terjadi saat ini mau tidak mau memberikan dampak terhadap berbagai sektor. Pada tataran ekonomi global, pandemi COVID-19 memberikan dampak yang sangat signifikan pada perekonomian domestik negara-bangsa dan keberadaan UMKM (Pakpahan, 2020). Kebijakan social distancing telah menurunkan secara drastis aktivitas dan pergerakan orang di Jabodetabek dan kota-kota besar. Hal ini dapat dilihat dari menurunnya jumlah penumpang pada berbagai sarana transportasi mulai pesawat terbang, kereta api komuter, bus dan busway, angkot, taksi, taksi online, bajaj, hingga ojek dan ojek online (Hadiwardoyo, 2020).

Berdasarkan hal tersebut, maka diperlukan suatu model untuk mengetahui faktor yang berpengaruh terhadap Covid-19. Penyebaran virus yang cepat dari suatu lokasi menuju lokasi lainnya mengindikasikan adanya efek spasial dalam pemodelan. Salah satu metode yang dapat digunakan dalam analisis spasial adalah Geographically Weighted Regression (GWR). Metode ini adalah suatu teknik yang membawa kerangka dari model regresi sederhana menjadi model regresi terboboti (Fotheringham et. al., 2002). Pada model regresi linier hanya dihasilkan estimator parameter yang berlaku secara global, sedangkan dalam model GWR dihasilkan estimator parameter model yang bersifat lokal untuk setiap lokasi pengamatan (Purhadi dan Yasin, 2008). Berdasarkan hal tersebut, penelitian ini akan terfokus pada pemodelan jumlah kasus Covid-19 beserta faktor-faktor ekonomi dan kependudukan di Provinsi Jawa Barat dengan menggunakan Geographically Weighted Regression.

\section{METODE}

Variabel dependen yang digunakan dalam penelitian ini adalah jumlah kasus Covid-19 di Provinsi Jawa Barat yang bersumber dari website Pusat Informasi dan Koordinasi Covid-19 Provinsi Jawa Barat (Pikobar) dan tercatat per tanggal 17 Agustus 2020. Dari segi kependudukan dan ekonomi, faktor-faktor yang digunakan pada penelitian ini serta dianggap memliki hubungan dengan penyebaran Covid-19 adalah kepadatan penduduk $\left(X_{1}\right)$, persentase kemiskinan $\left(X_{2}\right)$, tingkat pengangguran terbuka $\left(X_{3}\right)$, persentase rumah tangga dengan sanitasi layak $\left(X_{4}\right)$, dan persentase rumah tangga dengan sumber air minum layak $\left(X_{5}\right)$. Sebagai catatan, variabel $X_{2}, X_{3}$, $\mathrm{X}_{4}, \mathrm{X}_{5}$ merupakan data pada tahun 2019 yang tercatat terakhir kali oleh Badan Pusat Statistik Provinsi Jawa Barat (Badan Pusat Statistik, 2020). Metode yang digunakan dalam penelitian ini adalah Analisis Deskriptif dan Geographically Weighted Regression.

\section{Geographically Weighted Regression}

Geographically Weighted Regression (GWR) merupakan pengembangan dari regresi linear yang mana pada GWR berlaku secara lokal. Model ini menghitung parameter pada setiap lokasi pengamatan, sehingga setiap lokasi akan mempunyai model regresi yang berbeda-beda (Farida, 2016). Adapun bentuk model dari GWR adalah sebagai berikut:

$$
\mathbf{y}_{\mathrm{i}}=\boldsymbol{\beta}_{0}\left(\mathrm{u}_{\mathrm{i}}, \mathrm{v}_{\mathrm{i}}\right)+\sum_{\mathrm{k}=0}^{\mathrm{p}} \boldsymbol{\beta}_{\mathrm{k}}\left(\mathrm{u}_{\mathrm{i}}, \mathrm{v}_{\mathrm{i}}\right) \mathbf{x}_{\mathrm{ik}}+\boldsymbol{\varepsilon}_{\mathrm{i}}
$$

dimana:

$\mathbf{y}_{\mathrm{i}} \quad=$ nilai observasi variabel respon ke-i $; \mathrm{i}=1,2, \ldots, \mathrm{n}$

$\mathbf{x}_{\mathrm{ik}} \quad=$ nilai observasi variabel prediktor $\mathrm{k}$ pada pengamatan $\mathrm{ke}-\mathrm{i} ; \mathrm{k}=1,2, \ldots, \mathrm{p}$

$\boldsymbol{\beta}_{\mathrm{k}} \quad=$ koefisien regresi pada variabel prediktor $\mathrm{k}$

$\left(\mathrm{u}_{\mathrm{i}}, \mathrm{v}_{\mathrm{i}}\right)=$ titik koordinat (longitude, latitude) lokasi ke-i

$\varepsilon_{\mathrm{i}} \quad=$ error ke-i 


\section{Matriks Pembobot}

Dalam model GWR diperlukan matriks pembobot yang menunjukkan hubungan kedekatan antar lokasi. Adapun fungsi pembobot yang digunakan dalam penelitian ini adalah Fixed Exponential Kerne/ dengan formula sebagai berikut:

$$
\mathbf{w}_{\mathrm{j}}=\exp \left(\frac{\mathrm{d}_{\mathrm{ij}}}{\mathrm{h}}\right)
$$

dimana:

$\mathrm{d}_{\mathrm{ij}}=$ jarak euclidean antara lokasi ke-i ke lokasi ke-j.

$\mathrm{h}=$ bandwidth optimum yang fixed atau yang sama di semua lokasi.

Pemilihan bandwith optimum mempengaruhi ketepatan hasil estimasi parameter (Burnsdon et. al., 1996). Salah satu metode yang dapat digunakan adalah dengan menggunakan Cross Validation yang dituliskan sebagai berikut:

$$
\mathrm{CV}=\sum_{\mathrm{i}=1}^{\mathrm{n}}\left(\mathbf{y}_{\mathrm{i}}-\hat{\mathbf{y}}_{\neq \mathbf{i}}(\mathrm{h})\right)^{2}
$$

dimana:

$\mathbf{y}_{\mathrm{i}} \quad=$ nilai observasi variabel respon ke-i.

$\hat{\mathbf{y}}_{\neq \mathrm{i}}(\mathrm{h})=$ penaksir dimana pengamatan di lokasi ke-i dihilangkan dari proses penaksiran.

Pemilihan bandwitdh optimum diperoleh dari proses iterasi yang menghasilkan nilai CV yang minimum.

\section{Dependensi dan Heterogenitas Spasial}

Data spasial merupakan data yang memiliki karakteristik yaitu adanya dependensi spasial dan keragaman spasial. Dependensi spasial diukur untuk melihat apakah observasi di suatu lokasi berpengaruh terhadap observasi di lokasi lain yang berdekatan. Alat ukur dependensi spasial yaitu dengan menggunakan Indeks Moran dengan rumus sebagai berikut:

$$
\mathrm{Z}=\frac{\mathrm{I}-\mathrm{E}(\mathrm{I})}{\sqrt{\operatorname{var}(\mathrm{I})}} .
$$

\section{Dimana :}

$\mathrm{Z}=$ nilai statistik uji indeks moran

I = nilai indeks moran

Adapun keragaman spasial yang menjadi syarat dalam pemodelan GWR adalah heterogenitas spasial. Untuk mendeteksi ada atau tidaknya heterogenitas spasial dalam model dilakukan dengan uji Breusch-Pagan (Anselin, 1988). Adapun rumus formula yang digunakan pada uji Breusch-Pagan adalah sebagai berikut:

$$
\mathrm{BP}=\frac{1}{2} \mathbf{b}^{\mathrm{T}} \mathbf{A}\left(\mathbf{A}^{\mathrm{T}} \mathbf{A}\right)^{-1} \mathbf{A}^{\mathrm{T}} \mathbf{b}
$$

dimana:

$\mathrm{b}=$ vektor berukuran $1 \mathrm{xn}$ dengan $\mathrm{b}_{\mathrm{i}}=\frac{\mathrm{e}_{\mathrm{i}}^{2}}{\sigma^{2}}-1$

$\mathrm{e}_{\mathrm{i}}=$ residual pada pengamatan ke-i

$\sigma^{2}=$ varians dari residual

$\mathrm{A}=$ vektor dari variabel respon yang sudah dinormalbakukan untuk setiap pengamatan

\section{HASIL DAN PEMBAHASAN}

\section{Analisis Deskriptif}


Provinsi Jawa Barat terdiri dari 27 Kabupaten/Kota. Berdasarkan data dari Pikobar, diperoleh informasi bahwa jumlah kasus tertinggi berada di Kota Depok yaitu 1534 kasus terkonfirmasi Covid-19. Adapun jumlah kasus terendah berada di Kota Banjar yaitu 11 kasus terkonfirmasi Covid-19. Adapun peta sebaran Covid-19 di Jawa Barat dapat dilihat pada gambar 1.

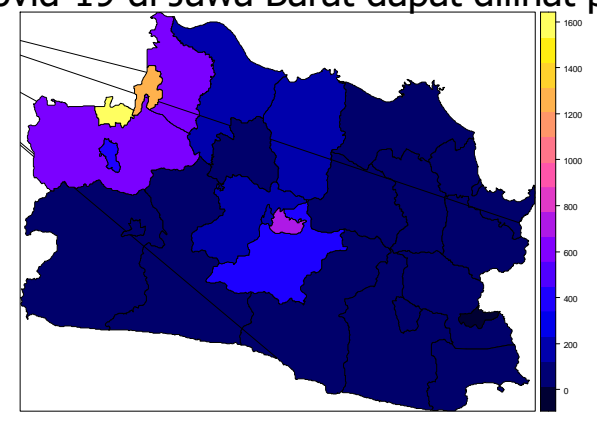

Gambar 1. Sebaran Covid-19 di Jawa Barat

Adapun deskriptif dari masing-masing variabel diperlihatkan pada tabel berikut:

Tabel 1. Deskriptif Data

\begin{tabular}{ccccc}
\hline Variabel & Minimum & Median & Rata-Rata & Maksimum \\
\hline Jumlah Kasus Covid-19 $(\mathrm{Y})$ & 11 & 88 & 258 & 1534 \\
Kepadatan Penduduk $\left(\mathrm{X}_{1}\right)$ & 398 & 1435 & 4100.9 & 15798 \\
Persentase Kemiskinan $\left(\mathrm{X}_{2}\right)$ & 2.07 & 7.48 & 7.407 & 11.6 \\
Tingkat Pengangguran Terbuka $\left(\mathrm{X}_{3}\right)$ & 4.37 & 8.17 & 7.794 & 10.280 \\
$\begin{array}{c}\text { Persentase Rumah Tangga dengan } \\
\text { Sanitasi Layak }\left(\mathrm{X}_{4}\right)\end{array}$ & 39.79 & 74.32 & 70.53 & 96.30 \\
$\begin{array}{c}\text { Persentase Rumah Tangga dengan } \\
\text { Sumber Air Minum Layak }\left(\mathrm{X}_{5}\right)\end{array}$ & 76.18 & 95.67 & 92.47 & 99.79 \\
\hline
\end{tabular}

\section{Analisis Regresi Linier}

Sebelum dilakukan pemodelan GWR, akan dilakukan regresi linier sebagai pemodelan secara global menggunakan estimasi OLS. Adapun hasil estimasi dari regresi global dapat dilihat pada tabel berikut:

Tabel 2. Estimasi Regresi Linier

\begin{tabular}{ccccc}
\hline Variabel & Estimasi & $\mathrm{t}$ & $P$-value & $R$-square \\
\hline Intersep & $9.340 \mathrm{e}-17$ & 0.000 & 1.0000 & \\
Kepadatan Penduduk $\left(\mathrm{X}_{1}\right)$ & $2.772 \mathrm{e}-01$ & 1.243 & 0.2274 & \\
Persentase Kemiskinan $\left(\mathrm{X}_{2}\right)$ & $-4.991 \mathrm{e}-01$ & -2.606 & 0.0165 & \\
\hline
\end{tabular}




\begin{tabular}{ccccc}
\hline Variabel & Estimasi & $\mathrm{t}$ & $P$-value & $R$-square \\
\hline Tingkat Pengangguran Terbuka $\left(\mathrm{X}_{3}\right)$ & $-2.610 \mathrm{e}-03$ & -0.019 & 0.9853 & $61.51 \%$ \\
$\begin{array}{c}\text { Persentase Rumah Tangga dengan } \\
\text { Sanitasi Layak }\left(\mathrm{X}_{4}\right)\end{array}$ & $1.803 \mathrm{e}-01$ & 1.167 & 0.2563 & \\
$\begin{array}{c}\text { Persentase Rumah Tangga dengan } \\
\text { Sumber Air Minum Layak }\left(\mathrm{X}_{5}\right)\end{array}$ & $3.831 \mathrm{e}-0.2$ & 0.205 & 0.8392 & \\
\hline
\end{tabular}

Berdasarkan hasil uji simultan diperoleh nilai statistik $\mathrm{F}=6.711$ dengan $\mathrm{p}$-value sebesar 0,0007 yang artinya variabel-variabel prediktor signifikan secara simultan terhadap jumlah kasus Covid-19. Sedangkan hasil uji parsial pada tabel 2 menunjukkan bahwa hanya pesentase kemiskinan yang berpengaruh signifikan terhadap jumlah kasus Covid-19 di Jawa Barat. Berdasarkan model regresi global ini, akan dilakukan pengujian dependensi spasial dan heterogenitas spasial yang merupakan asumsi yang harus terpenuhi pada model GWR. Hasil pengujian dengan menggunakan Indeks Moran dan Breusch-Pagan dapat dilihat pada tabel berikut:

Tabel 3. Indeks Moran dan Breush-Pagan

\begin{tabular}{ccc}
\hline Pengujian & P-value & Keterangan \\
\hline Indeks Moran & $4.214047 e-05$ & Signifikan \\
Breusch-Pagan & 0.01837 & Signifikan \\
\hline
\end{tabular}

Berdasarkan hasil pengujian, diperoleh informasi bahwa uji Indeks Moran dan Breusch-Pagan masing-masing menghasilkan nilai $\mathrm{p}$-value yang signifikan terhadap $\alpha(5 \%)$. Sehingga dapat disimpulkan bahwa terdapat dependensi spasial dan heterogenitas spasial. Dengan terpenuhinya asumsi ini maka pemodelan global tidak dapat digunakan karena akan menyebabkan estimasi parameter yang tidak efisien, sehingga pemodelan lokal melalui GWR diperlukan untuk dapat menjelaskan efek spasial pada data.

\section{Pemilihan Bandwidth}

Pemilihan bandwidth optimum diperoleh dengan meminimumkan nilai Cross-Validation (CV). Dengan menggunakan kernel eksponensial, hasil perhitungan CV dapat dilihat pada tabel berikut:

Tabel 4. Pemilihan Bandwidth Optimum berdasarkan Cross-Validation

\begin{tabular}{cc}
\hline Bandwidth & CV \\
\hline 1.145678 & 13.48044 \\
0.7082097 & 11.97755 \\
0.4378392 & 11.15187 \\
0.2707411 & 11.73391 \\
$\ldots$ & $\ldots$ \\
0.4192151 & 11.14352
\end{tabular}




\begin{tabular}{lc}
\hline Bandwidth & CV \\
\hline 0.4156582 & 11.1434
\end{tabular}

Berdasarkan hasil, diperoleh bandwidth optimum sebesar 0.4156582 dengan nilai CV minimum sebesar 11.1434.

\section{Pemodelan GWR}

Pembobotan pada GWR dilakukan dengan menggunakan matriks pembobot untuk setiap lokasi yang didasarkan pada bandwidth yang optimal. Adapun ringkasan dari estimasi parameter pada pemodelan GWR pada 27 Kabupaten/Kota di Jawa Barat dapat dilihat pada tabel 5 berikut:

Tabel 5. Pemodelan GWR

\begin{tabular}{ccccc}
\hline Variabel & Minimum & Median & Maksimum & $R$-square \\
\hline Intersep & -0.3181 & -0.0782 & 0.3325 & \\
Kepadatan Penduduk $\left(\mathrm{X}_{1}\right)$ & 0.1554 & 0.0747 & 0.3631 & \\
Persentase Kemiskinan $\left(\mathrm{X}_{2}\right)$ & -0.8242 & -0.5684 & -0.1192 & \\
Tingkat Pengangguran Terbuka $\left(\mathrm{X}_{3}\right)$ & -0.3627 & 0.0037 & 0.0917 & $92.97 \%$ \\
$\begin{array}{c}\text { Persentase Rumah Tangga dengan } \\
\text { Sanitasi Layak }\left(\mathrm{X}_{4}\right)\end{array}$ & -0.1572 & 0.0188 & 0.4372 & \\
$\begin{array}{c}\text { Persentase Rumah Tangga dengan } \\
\text { Sumber Air Minum Layak }\left(\mathrm{X}_{5}\right)\end{array}$ & -0.1057 & 0.0839 & 0.1936 & \\
\hline
\end{tabular}

Hasil pemodelan menunjukkan bahwa kepadatan penduduk memiliki hubungan positif terhadap jumlah kasus Covid-19, sedangkan persentase kemiskinan memiliki hubungan negatif terhadap jumlah kasus Covid-19. Adapun tingkat pengangguran terbuka, persentase rumah tangga dengan sanitasi layak, dan persentase rumah tangga dengan sumber air minum layak memiliki hubungan yang bervariasi untuk setiap lokasi pengamatan terhadap jumlah kasus Covid-19. Adapun seluruh nilai VIF lokal kurang dari 10. Hal ini mengindikasikan bahwa tidak ada masalah multikolinieritas lokal.

Tabel 6. Signifikansi variabel berdasarkan lokasi

\section{Lokasi Variabel Signifikan}

\begin{tabular}{lc}
\hline Kabupaten Karawang, Kabupaten Bekasi, Kota Bekasi & $\mathrm{X}_{1}, \mathrm{X}_{2}, \mathrm{X}_{3}$, dan $\mathrm{X}_{4}$ \\
$\begin{array}{l}\text { Kabupaten Bogor, Kabupaten Purwakarta, Kota Bogor, Kota Depok } \\
\text { Kabupaten Sukabumi, Kabupaten Cianjur, Kabupaten Subang, Kota } \\
\text { Sukabumi }\end{array}$ & $\mathrm{X}_{2}, \mathrm{X}_{3}$, dan $\mathrm{X}_{4}$ \\
Kota Bandung & $\mathrm{X}_{2}$ dan $\mathrm{X}_{4}$ \\
& $\mathrm{X}_{2}$ dan $\mathrm{X}_{5}$ \\
\hline
\end{tabular}


Kabupaten Bandung, Kabupaten Garut, Kabupaten Tasikmalaya, Kabupaten Cirebon, Kabupaten Majalengka, Kabupaten Sumedang, Kabupaten Indramayu, Kota Cirebon, Kota Cimahi, Kota Tasikmalaya, Kabupaten Bandung Barat

Kabupaten Pangandaran, Kabupaten Kuningan, Kota Banjar, Kota Ciamis

Tidak ada variabel signifikan

Berdasarkan hasil pada tabel 6, terbentuk 6 kelompok kabupaten/kota berdasarkan variabel yang signifikan. Kelompok 1 (Kabupaten Karawang, Kabupaten Bekasi, dan Kota Bekasi) dipengaruhi oleh kepadatan penduduk $\left(X_{1}\right)$, persentase kemiskinan $\left(X_{2}\right)$, tingkat pengangguran terbuka $\left(X_{3}\right)$, dan persentase rumah tangga dengan sanitasi layak $\left(X_{4}\right)$. Kelompok 2 (Kabupaten Bogor, Kabupaten Purwakarta, Kota Bogor, dan Kota Depok) dipengaruhi oleh persentase kemiskinan $\left(\mathrm{X}_{2}\right)$, tingkat pengangguran terbuka $\left(\mathrm{X}_{3}\right)$, dan persentase rumah tangga dengan sanitasi layak $\left(\mathrm{X}_{4}\right)$. Kelompok 3 (Kabupaten Sukabumi, Kabupaten Cianjur, Kabupaten Subang, dan Kota Sukabumi) dipengaruhi oleh persentase kemiskinan $\left(\mathrm{X}_{2}\right)$ dan persentase rumah tangga dengan sanitasi layak $\left(X_{4}\right)$. Kelompok 4 (Kota Bandung) dipengaruhi oleh persentase kemiskinan $\left(\mathrm{X}_{2}\right)$ dan persentase rumah tangga dengan sumber air minum layak $\left(\mathrm{X}_{5}\right)$. Kelompok 5 (Kabupaten Bandung, Kabupaten Garut, Kabupaten Tasikmalaya, Kabupaten Cirebon, Kabupaten Majalengka, Kabupaten Sumedang, Kabupaten Indramayu, Kota Cirebon, Kota Cimahi, Kota Tasikmalaya, Kabupaten Bandung Barat) dipengaruhi oleh persentase kemiskinan $\left(\mathrm{X}_{2}\right)$. Kelompok 6 (Kabupaten Pangandaran, Kabupaten Kuningan, Kota Banjar, Kota Ciamis) tidak dipengaruhi oleh variabel yang diteliti.

\section{KESIMPULAN}

Berdasarkan hasil analisis yang telah dilakukan, diperoleh kesimpulan bahwa pemodelan jumlah kasus Covid-19 di Jawa Barat secara lokal melalui GWR memiliki koefisien determinasi yang lebih tinggi dibanding pemodelan secara global melalui regresi linier. Hal ini sesuai dengan karakteristik dari data yang memenuhi asumsi dari GWR. Hasil pemodelan menunjukkan bahwa terbentuk 6 kelompok kabupaten/kota yang sebagian besar dipengaruhi oleh persentase kemiskinan. Adapun terdapat 4 lokasi yaitu Kabupaten Pangandaran, Kabupaten Kuningan, Kota Banjar, Kota Ciamis dipengaruhi oleh faktor selain kepadatan penduduk, persentase kemiskinan, tingkat pengangguran terbuka, persentase rumah tangga dengan sanitasi layak, maupun persentase rumah tangga dengan sumber air minum layak.

\section{UCAPAN TERIMA KASIH}

Ucapan terima kasih disampaikan kepada tim reviewer atas masukan untuk penyempurnaan jurnal ini, dan Pemerintah Provinsi Jawa Barat melalui tim Pusat Informasi dan Koordinasi Covid-19 Provinsi Jawa Barat (Pikobar) serta Badan Pusat Statistik Provinsi Jawa Barat yang telah menyediakan data penyebaran Covid-19 dan kondisi ekonomi di Provinsi Jawa Barat.

\section{DAFTAR PUSTAKA}

Anselin, L. (1988). Spatial Econometrics: methods and models, Dordrecht. Kluwer.

BPS Jawa Barat. (2020). Provinsi Jawa Barat Dalam Angka 2020. Badan Pusat Statistika Provinsi Jawa Barat. Bandung. 
Brundson, C., Fotheringham, A.S., dan Charlton., M.E. (1996). Geographically Weighted Regression : Method for Exploring Spatial Nonstationarity. Geographical Analysis, 28(4), 281-298.

Hadiwardoyo, W. (2020). Kerugian Ekonomi Nasional Akibat Pandemi Covid-19. BASKARA: Journal of Business \& Entrepreneurship, 2(2), 83-92. https://doi.org/10.24853/baskara.2.2.83-92

Hanoatubun, S. (2020). Dampak Covid-19 terhadap Perekonomian Indonesia. EduPsyCouns: Journal of Education, Psychology and Conseling, 2(1), 146-153.

Farida, I. (2016). Model Geographically Weighted Regression (GWR) dengan Pembobot Kernel Bisquare (Studi Kasus : Indeks Pembangunan Manusia (IPM) Tahun 2013 di Kabupaten dan Kota Provinsi Jawa Barat). Skripsi Universitas Pendidikan Indonesia. Bandung.

Fotheringham, A.S., Brundson, C. dan Charlton., M.E. (2002). Geographically Weighted Regression : The Analysis of Spatially Varying Relationship. John Wiley and Sons Ltd.

Kepres (Keputusan Presiden). (2020). Penetapan Kedaruratan Kesehatan Masyarakat Corona Virus Disease 2019 (COVID-19). Keputusan Presiden Republik Indonesia No. 11 Tahun 2020. Presiden Republik Indonesia. Jakarta

Pakpahan, A.K. (2020). Covid-19 dan Implikasi bagi Usaha Mikro, Kecil, dan Menengah. Jurnal Ilmiah Hubungan Internasional, 59-64.

PP (Peraturan Pemerintah). (2020). Pembatasan Sosial Berskala Besar Dalam Rangka Percepatan Penanganan Corona Wrus Disease 2019 (Covid-I9). Peraturan Pemerintah Nomor: 21 Tahun 2020. Presiden Republik Indonesia. Jakarta.

Purhadi dan Yasin. (2008). Mixed Geographically Weighted Regression Model (Case Study: the Percentage of Poor Households in Mojokerto 2008). European Journal of Scientific Research. 188-196.

RI (Republik Indonesia). (2018). Undang-Undang No. 6 Tahun 2018 Tentang Kekarantinaan Kesehatan. Lembaran Negara RI Tahun 2018, No. 128. Sekretariat Negara. Jakarta. 